Website: https://e-journal.iainsalatiga.ac.id/index.php/islah

\title{
Semiotics Integration in Understanding Story on Al Qur' an (Applying Narrative Theory of A.J Greimas towards the Story of the People of the Garden on QS. Al Qalam 17-32)
}

\author{
Muhammad Alwi HS \\ Fakultas Ushuluddin dan Pemikiran Islam, UIN Sunan Kalijaga \\ Muhalwihs2@gmail.com

\section{Iin Parninsih} \\ Fakultas Ushuluddin, UIN Syarif Hidayatullah \\ iin.parninsih@gmail.com
}

\begin{abstract}
Aiming to discuss the reading of semiotics in revealing the understanding story on $\mathrm{Al}$ Qur'an, this paper applies the narrative theory by A.J. Greimas on the story of the people of the Garden on QS. Al Qalam 17-32. This paper discusses the story due to the lack of research discussing about it, not limited to semiotics study. In fact, the story contains moral values that need to be elaborated. Therefore, starting from the assumption that the Qur'an through the story of the people of the garden has a moral ideal mission for mankind- especially Muslims, including both understanding within themselves and departing from outside scholar, this paper aims to prove the importance of the presence of stories in Al Qur'an through the integration of science outside Islam, namely semiotics. This research intends to answer the question on how to understand the narrative and moral ideals in the story of the garden owner in QS. Al-Qalam: 17-32 based on the narrative theory of A.J. Greimas.
\end{abstract}

Keyword: Story of the people of the Garden; QS. al-Qalam; Narrative, A.J. Greimas.

\begin{abstract}
Abstrak
Tulisan ini hendak mendiskusikan pembacaan semiotika dalam mengungkap pemahaman atas kisah dalam al-Qur'an, yang dalam hal ini akan berfokus pada penerapan teori naratif dari A.J. Greimas atas kisah pemilik kebun dalam surah al-Qalam ayat 17-32. Pengambilan kisah pemilik kebun disebabkan masih sangat minimnya penelitian yang membahas kisah tersebut, termasuk pembacaan semiotika yang belum dilakukan. Padahal dalam kisah tersebut mengandung nilai moral yang perlu diungkapkan. Karena itu, berangkat dari asumsi bahwa al-Qur'an melalui kisah pemilik kebun memiliki misi ideal moral untuk umat manusia -khususnya umat Islam, baik pemahaman dalam dirinya sendiri maupun berangkat dari keilmuan dari luar, maka tulisan ini akan membuktikan nilai penting kehadiran kisah dalam al-Qur'an melalui integrasi keilmuan di luar islam, yakni semiotika. Adapun rumusan masalah yang hendak dijawab dalam tulisan ini adalah bagaimana pemahaman narasi dan ideal moral dalam kisah pemilik kebun pada QS. Al-Qalam: 17-32 berdasarkan teori naratif A.J. Greimas.
\end{abstract}

Keyword: Kisah Pemilik Kebun; QS. al-Qalam; Naratif, A.J. Greimas. 


\section{INTRODUCTION}

As a guidebook for human life, especially Muslims (QS. Al-Baqarah: 02 dan 185), Al Qur'an receives special attention for being studied. Since there are many forms of study born from this holy book, this book is also well known as shalihu li kulli zaman wa makan. Husein Aziz in his research, for example, concludes that one of the miracles of Al Qur'an which always excels and achieves novelty in this modern times. ${ }^{1}$ Therefore, this paper examines on the miracles of $\mathrm{Al}$ Quran based on the story written on Al Qur'an. That written stories always gives important lessons for Muslims. $^{2}$

In this paper, the story is integrated with semiotic discourse, as a secular study. Semiotics is a branch of science which performs a significant influence, both as a method of study (decoding) and as a method of creation (encoding). ${ }^{3}$ Some semiotic experts - as suggested by Yasraf Amir - such as Umberto Eco, Roland Barthes, Coward and Ellis, agree that discussion of semiotics is not limited by anything who gives the sign, including humans, animals, even God. Furthermore, as long as the sign is used in a same system and communication, not to mention accepted by the sender and the receiver, it belongs to semiotics study including the study of sign and the study of religion. ${ }^{4}$ Moreover, according to Ahmad Muzakki, Al Qur'an which is as an object of semiotics study, is in a written form (Mushaf), not in a form before it is written, ${ }^{5}$ not limited to the stories in it.

Basically, there are many studies discussing stories in Al Qur'an in a form of compilation focusing in a story. For example, Qishashul al-Qur'an (the master book of stories in Al Qur'an) by Muhammad Ahmad Jadul et.al ${ }^{6}$ discusses the story of People of the Garden, the story which is as the focus in this study. Other books are such as Seri Kisah-kisah dalam al-Qur'an (Series $1^{7}$ and $2^{8}$ ) by Bung Smas, Al-Aabaa wal Abnaa fil Qur'anil Karim (the story of Father and Son in Al Qur'an)

\footnotetext{
${ }^{1}$ See further on Husein Aziz, 'Kontekstualisasi Kemukjizatan Sastrawi Al-Qur'an', Islamica, 11.2 (2017), 418.

${ }^{2}$ M. Quraish Shihab gives some conclusions from the stories on Al Qur'an. First, stories related personally to humans show that there are lessons or examples that can be learned. Even the stories told the bad side or weakness of humans, Al Qur' an always gives insight in concluding the story. Second, the story displaying situation of a community is an attempt to take lessons, both from the factors causing a community falls or factors causing a community civilized. See further on M. Quraish Shihab, Kaidah Tafsir: Syarat, Ketentuan, Dan Aturan Yang Patut Anda Ketahui Dalam Memahami Ayat-Ayat Al-Qur'an (Tangerang: Lentera Hati, 2013).

${ }^{3}$ Yasraf Amir Piliang, Hipersemiotika: Tafsir Cultural Studies Atas Matinya Makna (Yogyakarta: Jalasuta, 2003), p. 255.

${ }^{4}$ Yasraf Amir Piliang, Semiotika Dan Hipersemiotika: Gaya, Kode, Dan Matinya Makna (Bandung: Matahari, 2012), p. 362.

${ }^{5}$ Ahmad Muzakki, Kontribusi Semiotika Dalam Memahami Bahasa Agama(Malang: UIN Malang, 2007), p. 101.

${ }^{6}$ Muhammad Ahmad Jadul, Muhammad Abu Fadli Ibrahim, and Dkk., Buku Induk Kisah Al-Qur'an, trans. by Abdurrahman Assegaf, 2009.

${ }^{7}$ Bung Smas, Seri Kisah-Kisah Dalam Al-Qur'an Seri 1 (Bandung: Remaja Rosdakarya, 2012).

${ }^{8}$ Bung Smas, Seri Kisah-Kisah Dalam Al-Qur'an Seri 2 (Bandung: Remaja Rosdakarya).
} 
by Adil Musthafa Abdul Halim ${ }^{9}, M a$ 'a Qashashis-Saabiqiina fil-Qur'an (The stories in Al Qur'an) by Shalah Abdul Fattah al-Khalidy ${ }^{10}$, Kisah-kisah Pembebasan dalam al-Qur'an by Eko Prasetyo ${ }^{11}$, and many more works revealing stories in Al Qur'an.

Furthermore, the stories of Al Qur'an which are integrated with semiotics study have also widely carried out which can be seen, such as in Semiotika al-Qur'an: Metode dan Aplikasi terhadap Kisah Yusuf by Ali Imron ${ }^{12}$, thesis Kisah Zu Al-Qarnain dalam al-Qur'an (Telaah Semiotik) by Nor Faridatunnisa ${ }^{13}$ and other works. Specifically, semiotics study using narrative theory proposed by A.J. Greimas has also been carried out which can be seen in Aplikasi Semiotika Naratif A.J. Greimas terhadap Kisah Thalut dalam al-Qur'an by Nor Istiqomah. ${ }^{14}$ Moreover, there are more studies discussing the stories in Al Qur'an which are not sufficiently explained in this paper. The study of stories in Al Qur'an is Islamic scientific heritage that is worth studying, while semiotics has a portion in providing an understanding of stories in Al Qur'an. However, over the various studies mentioned above, there is only one book which discusses about the People of the Garden, yet it is only in a chapter. Therefore, in order to develop the study of the People of the Garden, this study discuss it as a semiotic study focussing on applying narrative theory suggested by A.J.Greimas.

\section{METHODOLOGY}

This study uses a descriptive-analytical method focusing on applying theory suggested by A.J.Greimas on narrative. The primary data is QS. Al Qalam verses 17 - 32, while the secondary data are all sources (books, journal, articles, etc.) related to this study. This study has two main objectives, including, first, to prove that semiotics study is able to reveal the content of Al Qur'an, in this case the narrative theory of Greimas. Second, this study aims to export the understanding of the story of the People of the Garden in QS. Al Qalam 17 - 32.

\footnotetext{
${ }^{9}$ Adil Musthafa Abdul Halim, Kisah Bapak Dan Anak Dalam Al-Qur'an, trans. by Abdul Hayyie Al-Katani and Fitriah Wardie (Jakarta: Gema Insani, 2007).

${ }^{10}$ Shalah Abdul Fattah Al-Khalidy, Kisah-Kisah Al-Qur'an, trans. by Setiawan Budi Utomo (Jakarta: Gema Insani, 2000).

${ }^{11}$ Eko Prasetyo, Kisah-Kisah Pembebasan Dalam Al-Qur'an (Yogyakarta: Resist Book, 2012).

${ }^{12}$ Ali Imron, Semiotika Al-Qur'an: Metode Dan Aplikasi Terhadap Kisah Yusuf(Yogyakarta: Teras, 2011). This book is a follow up work of the writer's thesis. See Ali Imron, 'Kisah Nabi Yusuf A.S. Dalam Al-Qur'an' (UIN Sunan Kalijaga, 2010).

${ }^{13}$ Nor Faridat unnisa, 'Kisah-Kisah Zu Al-Qurnain Dalam Al-Qur'an' (UIN Sunan Kalijaga, 2015).

${ }^{14}$ Nor Istiqomah, ‘Aplikasi Semiotika Naratif A.J. Greimas Terhadap Kisah Thalut Dalam Al-Qur’an', Qof, 1.2 (2017).
} 


\section{DISCUSSION}

\section{A.J. Greimas and The Theory of Narrative}

Algirdas Julian Greimas is a great scholar promoting structural theory. ${ }^{15}$ Greimas was born in Russia, in Tula area on March $9^{\text {th }}, 1917$. He graduated form University of Grenoble in 1939 majoring law. Around 1940, he returned to his hometown, Lithuania, to teach and work as an editor and wrote various articles on literary-criticism and cultural-criticism. Four years later (1944), he returned back to France to pursue doctoral studies and wrote doctoral thesis entitles "Le Mode en 1830: Essai de Descrition du vocabulaire de I'epoque" in 1949. Some of his famous works are semantique stuctural (Structural Semantic, 1983), Mythology (On Gods and Men, 1979), and In Search of National Memory). He died in $1992 .{ }^{16}$

Greimas developed structural theory into narrative structural and formulated the concept of a narrative unit called actant, at this point he continued and promoted Propp's theory. ${ }^{17}$ In terms of language, actant means actions born from living things providing syntactic units. ${ }^{18}$ Greimas' narrative theory emerged from the basic assumption that narrative texts are composed of structural dyadic analogies in linguistics based on Saussure on the one hand and Propp's theory on the other hand. Furthermore, he summarizes Propp's concept of 31 action functions into 20 functions and divided it into three syntagmas including Syntagmes Contractuels (based on aggreement), Syntagmes Performanciel (organizational), dan Syntagmes Disjontionnels (disconnection). ${ }^{19}$

Furthermore, in his semiotics theory, Greimas sees two element which consistently present including external structural element which is clearly illustrated in the arrangement of words or sentences and internal structural element which is understood beneath the arrangement of words or sentences. In order to find out the external structural element of a text, there is a classification of the actants which is shown below: ${ }^{20}$

\footnotetext{
${ }^{15}$ See preface by Frederic Jameson on Algirdas Julien Greimas, On Meaning Selected Writing in Semiotic Theory, trans. by Perron and Frank H. Collins (Canada: University of Minnesota Press, 1987), p. iv.

${ }^{16}$ Istiqomah, pp. 80-81.

${ }^{17}$ Cyntia Dewi Anggraini and Et.al, 'Analisis Struktural Naratif Algirdas Greimas Pada Artikel Storytelling Project Sunlight PT. Unilever Indonesia Pada Bulan November 2014', in E-Proceeding of Management, 2014, p. 931.

${ }^{18}$ Algirdas Julien Greimas and J. Courtes, Semiotika and Language: An Anlytical Dictionary (Bloomington: Indiana University Press, 1982), p. 5.

${ }^{19}$ Kukuh Yudha Karnanta, 'Struktural (Dan) Semantik: Teropong Strukturalisme Dan Aplikasi Teori Naratif A.J. Greimas', Atavisme, 18.2 (2015), p. 175.

${ }^{20}$ Istiqomah, p. 81. See also Wildan Taufiq, Semitika Untuk Kajian Sastr Dan Al-Qur'an (Bandung: Yrama Widya, 2016).
} 
Table 1. Classification of the Actants

\begin{tabular}{cc}
\hline Actant & Meaning \\
\hline $\begin{array}{c}\text { Adressant/Senders } \\
\text { Adressat/Receivers }\end{array}$ & $\begin{array}{c}\text { The reference that sets the rules and values as well as ideology of the text } \\
\text { The value bearer from the destinator/object where the destinator places the } \\
\text { value }\end{array}$ \\
$\begin{array}{c}\text { Subject } \\
\text { Object }\end{array}$ & Main character in nattarion \\
Adjuvant/Helpers & What the subject wants to achieve (the goal) \\
Opponents/Traitor & Supporting the subject to achieve the goal (object) \\
Preventing the subject to achieve the goal (object)
\end{tabular}

The various actants mentioned above is depicted on the following picture. ${ }^{21}$

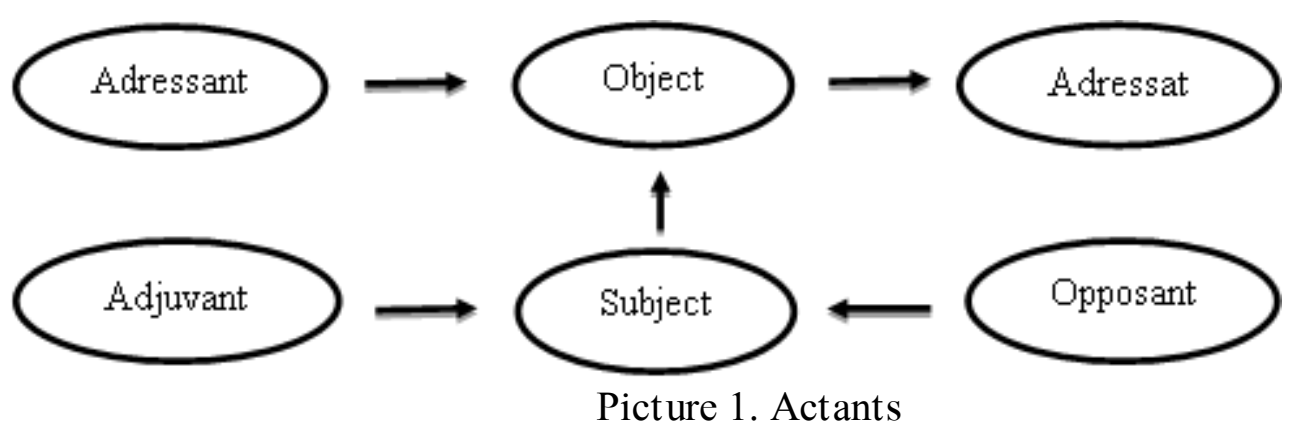

As for internal structural element, there is Greimas Semiotic Square which is shown as follows: $:^{22}$

Table 2. Greimas Semiotic Square

\begin{tabular}{cc}
\hline Relation Type & Relation Element \\
\hline Opposition & $\mathrm{S} 1+\mathrm{S} 2$ \\
Opposition & $-\mathrm{S} 2+-\mathrm{S} 1$ \\
Contradiction & $\mathrm{S} 2+-\mathrm{S} 2$ \\
Contradiction & $\mathrm{S} 2+\mathrm{S} 1$ \\
Implication & $-\mathrm{S} 2+\mathrm{S} 1$ \\
Implication & $-\mathrm{S} 1+\mathrm{S} 2$ \\
\hline
\end{tabular}

\footnotetext{
${ }^{21}$ Alirdas Julien Greimas, Struktural Sematik: Methodologiesche Untersuchungen, trans. by Gilon Auge and Et.al (New York: Pergamon Press, 1971), p. 165.

${ }^{22}$ Istiqomah, p. 82.
} 
The element can also be represented in the following picture. ${ }^{23}$

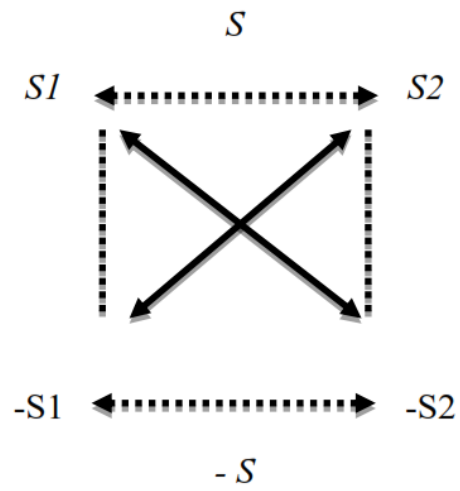

Picture 2. The elementary structure of meaning

Moreover, there are several methodical steps - as stated by Nor Istiqomah - used in Greimas narrative semiotics including as follows: ${ }^{24}$

1. Providing a general explanation of stories in certain divided segment;

2. Determining the actant in each segment;

3. Creating structure of a functional text;

4. Determining the relationship between actants, so the main actants is clearly shown through the entire segments;

5. Determining the structure of a text;

6. Analyzing the inner structural element of each segment by referring the inner structural formula;

7. Determining the overall inner structural element; and

8. Drawing conclusions.

\section{The Application of the Theory of Narrative by Greimas on the story of the People of the}

\section{Garden}

Found in QS Al Qalam verses 17 - 31 (16 verses), the story of the People of the Garden according to Quraish Shihab - was familiar among the musyrikin in Mecca, when these verses were revealed, namely Dharawan area near Shan'a, Yemen. ${ }^{25}$ The characters' name is not clearly stated. However, in general, the story tells about the people who owners the garden got punishment due to their stinginess for sharing their garden harvest with the poor.

\footnotetext{
${ }^{23}$ Algirdas Julien Greimas, p. 49.

${ }^{24}$ Istiqomah, p. 82.

${ }^{25}$ M. Quraish Shihab, Tafsir Al-Misbah: Pesan, Kesan, Dan Keserasian Al-Qur'an (Jakarta: Lentera Hati, 2011), XIV, p. 387.
} 
At the beginning of the story, Allah made this story as an example for people (musyrik in Mecca) who were given a test, in which Allah made the garden harvest as a test for its owner. The owners are reluctant - even unwilling - to distribute their garden harvest to the poor. Their action made Allah sent down the punishment by burning (scorching) their gardens at night. In the next morning, when they went to their gardens to harvest their garden harvest, they saw that their gardens have been burned down. Witnessing the condition of their garden, the people of the garden realized that the sins they had committed caused this problem happened. Therefore, they immediately realized, repented, asked for forgiveness of their sins, and ask for a better condition of their gardens.

The story above, in Qishashul Qur'an, is explained further, especially regarding the garden which was an inheritance from the father of the people of the garden. It was explained that the very fertile garden in Dharawan area belonged to a Sheikh from Bani Israel who was famous for being pious and generous. Every garden harvest was distributed to the poor. This habit continues until death picked him up. Before he died, he made a will to his children to continue the habit of distributing the garden harvest even after his death. ${ }^{26}$ However, the will was not heeded by his children. Therefore, Allah punished his children as the owner of the garden.

a. Actant 1 in $1^{\text {st }}$ Segment

The first actant in the story of the people of the garden in QS. Al Qalam 17 - 18 is in the beginning of the story of the people of the garden. In the first segment, the theme is "test for the people of the garden" which is shown on the following verse.

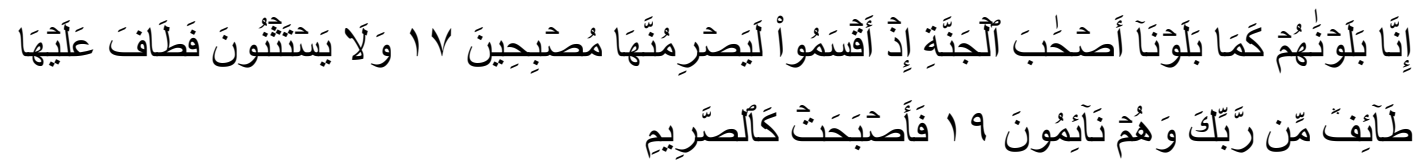

"Indeed, We have tried them as We tried the companions of the garden, when they swore to cut its fruit in the [early] morning Without making exception So there came upon it [i.e., the garden] an affliction from your Lord while they were asleep And it became as though reaped."

The actants of the first segment are:

Sender: Garden

Receiver: the poor

${ }^{26}$ The full version of this story can be read in Jadul, Ibrahim, and Dkk., pp. 355-60. 
Subject: The people of the garden

Object: Garden harvest

Helper: strong desire to pick the garden harvest

Opposant: Scorched garden

The sender of the first segment is the garden. In the story, the people of the garden are the subject of the story who have a strong desire to pick their garden harvest. Their strong will of the people of the garden is called as Helper. Furthermore, the strong desire to own all the garden harvest made the people of the garden determined not to distribute it to the poor - as their father used to do. In this first segment, the poor is as Receiver of the people of the garden action. Due to the arrogance and stinginess of the people of the garden, Allah gave them punishment by burning down their gardens at night. The burning of the gardens, in this story, acts as Opposant.

b. Actant 2 in $2^{\text {nd }}$ Segment

The second segment of the story of the people of the garden is about "the stinginess of the people of the garden" in QS. Al Qalam verses 21 - 25. The verses is in the following data.

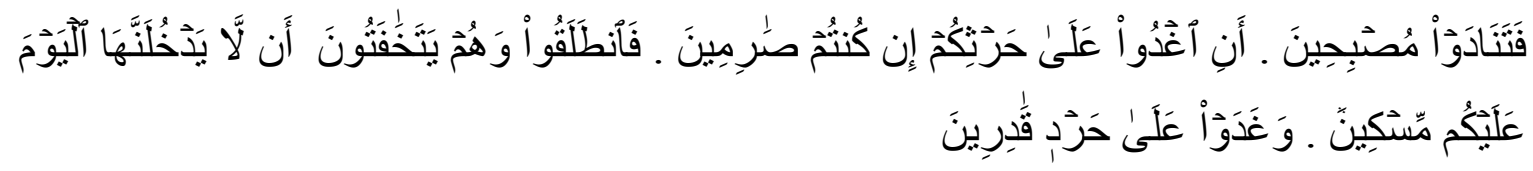

"And they called one another at morning, [Saying], "Go early to your crop if you would cut the fruit. So they set out, while lowering their voices, [Saying], "There will surely not enter it today upon you [any] poor person. And they went early in determination, [assuming themselves] able."

The actants of the second segment are:

Sender: Stinginess

Receiver: Other owner of other garden

Subject: The people of the garden

Object: Harvesting

Helper: determination to deter the poor

Opposant: The poor's right

The Sender of the second segment above is the stinginess inherent in the character of the people of garden. In this story, there is a dialogue between the owner of the garden with other. The people of the garden plan to harvest their garden without the presence of the poor. The people of the garden acts as Subject of the second segment of the story. The 
other owner of the garden who participate to the plan become Receiver. In the next early morning, they get up to harvest their garden. Here, picking up fruits is the Object of the Story. Their efforts in harvesting their garden are accompanied by a strong determination to prevent the poor from participating in harvesting their gardens. In this context, the determination to deter the poor becomes Helper. They do not realize that there is a right to the poor as they have helped them. The poor's right in the story acts as Opposant.

c. Actant 3 in $3^{\text {rd }}$ Segment

The third segment with the theme "The People of the Garden Repent" is in QS. Al Qalam verses $26-32$. The verses are shown below.

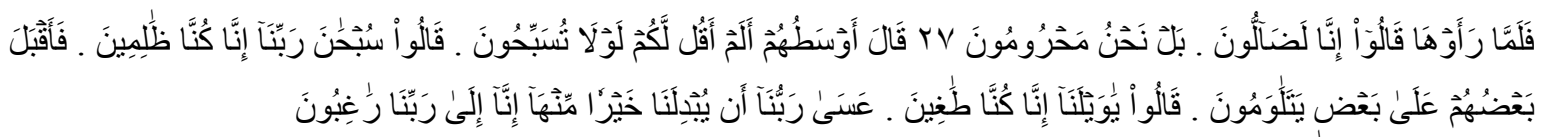

"But when they saw it, they said, "Indeed, we are lost; Rather, we have been deprived. The most moderate of them said, "Did I not say to you, 'Why do you not exalt [Allāh]? They said, "Exalted is our Lord! Indeed, we were wrongdoers. Then they approached one another, blaming each other. They said, "O woe to us; indeed we were transgressors. Perhaps our Lord will substitute for us [one] better than it. Indeed, we are toward our Lord desirous."

The actants of the third segment are:

Sender: Repentance

Receiver: Other owner of other garden

Subject: The people of the garden who is kind

Object: Allah forgiveness

Helper: prayer

Opposant: -

In the third segment, the Sender is Repentance which is initiated by the people's awareness when he witnessed the condition of his garden which has been scorched. The kind one becomes the Subject in the story and advises his other brothers. The other garden owners act as Receivers. After realizing their sins and mistakes, the people of the gardes asked for forgiveness from Allah. In this context, God's forgiveness becomes the Object in this story. In order to expedite the confession and forgiveness of the people of the garden, they pray "Exalted is our Lord! Indeed, we were wrongdoers." and "Perhaps our Lord will substitute for us [one] better than it. Indeed, we are toward our Lord 
desirous." Their prayer acts as Helper. In their request for asking for forgiveness, there is no obstacles (Opposant) that they find.

\section{d. Functional Structure}

This section shows a map of actants, so the narrative of the people of the garden is easier to understand. Moreover, the functional structure of each actant in the story of the people of the garden is shown below.

Table 3. The Functional Structure

\begin{tabular}{|c|c|c|c|}
\hline & Actant 1 & Actant 2 & Actant 3 \\
\hline Sender & Garden & Stinginess & Repentance \\
\hline Receiver & the poor & $\begin{array}{l}\text { Another owner of other } \\
\text { garden }\end{array}$ & $\begin{array}{l}\text { Another owner of other } \\
\text { garden }\end{array}$ \\
\hline Subject & The people of the garden & The people of the garden & $\begin{array}{c}\text { The people of the garden } \\
\text { who is kind }\end{array}$ \\
\hline Object & Garden harvest & Harvesting & Allah forgiveness \\
\hline Helper & $\begin{array}{l}\text { Strong desire to pick the } \\
\text { garden harvest }\end{array}$ & $\begin{array}{l}\text { Determination to deter the } \\
\text { poor }\end{array}$ & prayer \\
\hline Opposant & Scorched garden & The poor's right & - \\
\hline
\end{tabular}

\section{e. Main Actant}

In order to find the main actant in this story, it is necessary to explain the previous overall actants. Furthermore, the actants are analyzed by looking for the relation between an actant and others. The actants are as follows:

In Actant Sender, there is a relation between an actant ant others including garden, stinginess, and repentance. Those three actants are connected in the existence of problemsolving, and due to the stinginess of them they got punishment by God until they repent. The most dominant Actant Receiver is the other owner of the garden who had bad character. The Actant Subject in this story is the people of the garden who give overview of their character though Sender that they face. The Actant Object in this story is the benefit of the garden which is seen implicitly in each first, second, and third actant. The harvest garden and picking up the fruits clearly refer to the garden, while the forgiveness from Allah refers to the request for the return of their garden to its original condition (or a better one). The Actant Helper of this story is like a wave motion which is initially only intended (Actant 1) then becomes action (Actant 2), until finally awakened and they prayed (Actant 3). The Actant Opposant is the burning of the gardens and the rights of the poor. 
Therefore, the main Actant of the people of the garden is displayed below.

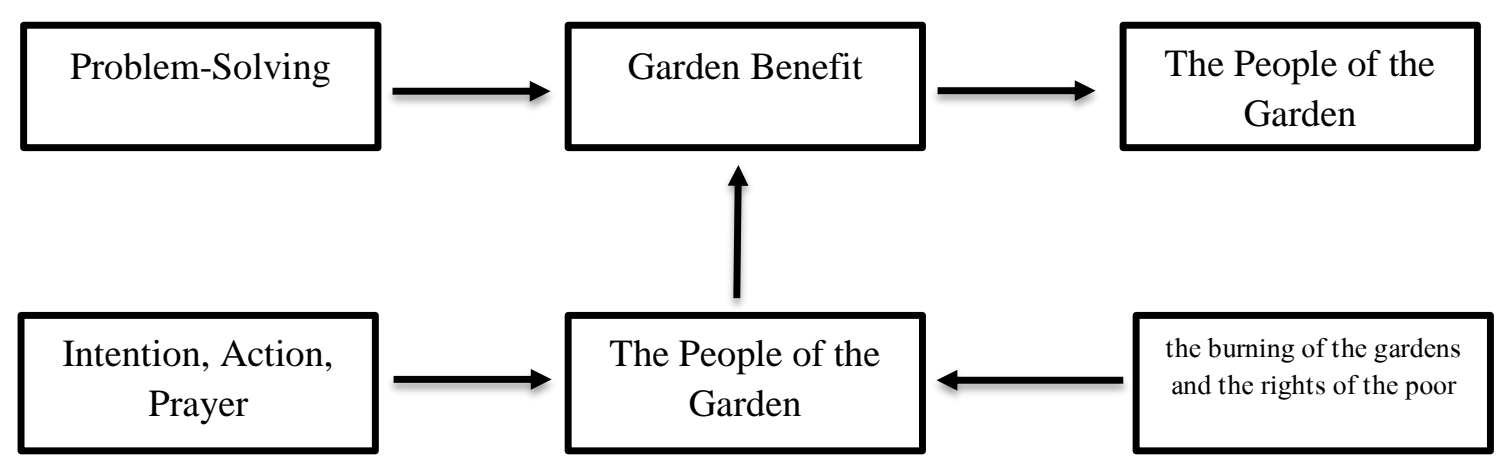

Picture 3. The Main Actant of The People of The Garden

Therefore, the external element structure from the people of the garden describes the people of the garden in using their garden for a proper utilization which is in line with the problem-solving (solutions) they face. Their intentions and actions end with awareness (prayer), so that they return to the straight path. However, they feel the condition of their scorched garden and pay attention to their rights of the poor.

\section{f. Internal Structure}

The internal structure contained in each actant segment is follows:

1. Fantasy : disappointment :: not fantasy : no disappointment

2. Ambition : unaware :: no ambition : aware

3. Repentance : humble :: not repentance : not humble

The internal structure captured from Al Qur'an, especially the one that discusses the story of the people of the garden is how the story illustrates the human weakness in his plans (fantasy - ambition - repentance). When someone got bigger responsibility, at the same time he realizes that he is unable to bear it by himself, and forgetting other party (God and other human) means harming himself.

\section{CONCLUSION (Times New Arabic, 12pt, Bold, Capital Letters)}

From the various explanations in the previous sections, it can be concluded as follows:

1. In general, this story tells about the punishment for the people of the garden for their stinginess in sharing their harvest garden to the poor. The owners are reluctant - even unwilling - to distribute their garden harvest to the poor. Their action made Allah sent down the punishment by burning (scorching) their gardens at night. In the next morning, when they went to their gardens to harvest their garden harvest, they saw that their 
gardens have been burned down. Witnessing the condition of their garden, the people of the garden realized that the sins they had committed caused this problem happened.

2. In the story of the people of the garden, Greimas's narrative theory works in describing the character of the people who is stingy but quickly awakens. Here, this story seeks to raise problem-solving. Their intentions and actions end with an awareness (prayer) and come back to the straight path. However, they felt a condition in which their garden ware burned down and paid attention to the poor's right.

3. Through this story, it is implied a message (inner meaning) from Allah that anything you may have and proud of is only a test from Him in which you need to use it wisely. Moreover, related to human awareness of their limitation, another message is implied that they always need a help from Allah and others.

\section{REFERENCES}

Al-Khalidy, Shalah Abdul Fattah, Kisah-Kisah Al-Qur'an, trans. by Setiawan Budi Utomo (Jakarta: Gema Insani, 2000)

Anggraini, Cyntia Dewi, and Et.al, 'Analisis Struktural Naratif Algirdas Greimas Pada Artikel Storytelling Project Sunlight PT. Unilever Indonesia Pada Bulan November 2014', in E-Proceeding of Management, 2014

Aziz, Husein, 'Kontekstualisasi Kemukjizatan Sastrawi Al-Qur'an', Islamica, 11.2 (2017), 418

Faridat unnisa, Nor, 'Kisah-Kisah Zu Al-Qurnain Dalam Al-Qur’an’ (UIN Sunan Kalijaga, 2015)

Greimas, Algirdas Julien, On Meaning Selected Writing in Semiotic Theory, trans. by Perron and Frank H. Collins (Canada: University of Minnesota Press, 1987)

Greimas, Algirdas Julien, and J. Courtes, Semiotika and Language: An Anlytical Dictionary (Bloomington: Indiana University Press, 1982)

Greimas, Alirdas Julien, Struktural Sematik: Methodologiesche Untersuchungen, trans. by Gilon Auge and Et.al (New York: Pergamon Press, 1971)

Halim, Adil Musthafa Abdul, Kisah Bapak Dan Anak Dalam Al-Qur'an, trans. by Abdul Hayyie Al-Katani and Fitriah Wardie (Jakarta: Gema Insani, 2007)

Imron, Ali, 'Kisah Nabi Yusuf A.S. Dalam Al-Qur'an' (UIN Sunan Kalijaga, 2010)

_- Semiotika Al-Qur'an: Metode Dan Aplikasi Terhadap Kisah Yusuf(Yogyakarta: Teras, 2011)

Istiqomah, Nor, 'Aplikasi Semiotika Naratif A.J. Greimas Terhadap Kisah Thalut Dalam AlQur'an', Qof, 1.2 (2017)

Jadul, Muhammad Ahmad, Muhammad Abu Fadli Ibrahim, and Dkk., Buku Induk Kisah Al- 
Qur'an, trans. by Abdurrahman Assegaf, 2009

Karnanta, Kukuh Yudha, 'Struktural (Dan) Semantik: Teropong Strukturalisme Dan Aplikasi Teori Naratif A.J. Greimas', Atavisme, 18.2 (2015)

Muzakki, Ahmad, Kontribusi Semiotika Dalam Memahami Bahasa Agama (Malang: UIN Malang, 2007)

Piliang, Yasraf Amir, Hipersemiotika: Tafsir Cultural Studies Atas Matinya Makna (Yogyakarta: Jalasuta, 2003)

— - Semiotika Dan Hipersemiotika: Gaya, Kode, Dan Matinya Makna (Bandung: Matahari, 2012)

Prasetyo, Eko, Kisah-Kisah Pembebasan Dalam Al-Qur'an(Yogyakarta: Resist Book, 2012)

Shihab, M. Quraish, Kaidah Tafsir: Syarat, Ketentuan, Dan Aturan Yang Patut Anda Ketahui Dalam Memahami Ayat-Ayat Al-Qur'an (Tangerang: Lentera Hati, 2013) , Tafsir Al-Misbah: Pesan, Kesan, Dan Keserasian Al-Qur'an (Jakarta: Lentera Hati, 2011), XIV

Smas, Bung, Seri Kisah-Kisah Dalam Al-Qur'an Seri 1 (Bandung: Remaja Rosdakarya, 2012)

—, Seri Kisah-Kisah Dalam Al-Qur'an Seri 2 (Bandung: Remaja Rosdakarya)

Taufiq, Wildan, Semitika Untuk Kajian Sastr Dan Al-Qur'an (Bandung: Yrama Widya, 2016) 